\title{
Microstructure and Microhardness Evolutions of High Fe Containing Near-Eutectic Al-Si Rapidly Solidified Alloy
}

\author{
Emad M. Ahmed ${ }^{1,2}$ and M. R. Ebrahim ${ }^{2}$ \\ ${ }^{1}$ Physics Department, Faculty of Science, Taif University, P.O. Box 888, Taif 21974, Saudi Arabia \\ ${ }^{2}$ Solid State Physics Department, National Research Center, Dokki, Giza 12311, Egypt
}

Correspondence should be addressed to Emad M. Ahmed; makboul67@yahoo.com

Received 30 November 2013; Accepted 4 March 2014; Published 25 May 2014

Academic Editor: Gerhard Sauthoff

Copyright (C) 2014 E. M. Ahmed and M. R. Ebrahim. This is an open access article distributed under the Creative Commons Attribution License, which permits unrestricted use, distribution, and reproduction in any medium, provided the original work is properly cited.

\begin{abstract}
Al-11 wt.\% Si-11 wt.\% Fe (11.29 at.\% Si-5.6 at.\% Fe) melt was rapidly solidified into ribbons and characterized by X-ray diffraction (XRD), scanning electron microscopy (SEM), energy dispersive X-ray spectroscopy (EDS), and microhardness technique. The Rietveld X-ray diffraction analysis was applied successfully to analyze microstructure and phase precipitations. On the basis of the aluminum peak shifts measured in the XRD scans, a solid solubility extension value of 1 at.\% Si in $\alpha$-Al was determined. SEM investigations confirmed presence of a spherical shape $\alpha$-phase particles in addition to needle and spherical shape $\beta$-phase particles with contents of $1.1 \mathrm{wt} . \%$ and $10.1 \mathrm{wt} . \%$ as deduced by XRD analysis. During prolonged annealing process at $350^{\circ} \mathrm{C} / 25 \mathrm{~h}, \alpha$-phase disappeared, $\beta$-phase content increased to $30 \mathrm{wt}$.\%, and Si presence becomes more evident as deduced by XRD analysis. EDS analysis confirmed that these $\beta$ particles observed in the as-melt spun alloy are of lower Fe content comparing to those usually observed in the as-cast counter-part alloy. Besides, the length distribution of needle shape $\beta$-particles has been shortened to be diverse from 1 to $5 \mu \mathrm{m}$. The as-melt spun ribbons exhibited enhancement of hardness to $277 \mathrm{HV}$ and further increased during heat treatment $\left(150^{\circ} \mathrm{C} / 12 \mathrm{~h}\right)$ to $450 \mathrm{HV}$. This improvement of microstructure and hardness are the influence of microstructural refinement and modification obtained during the rapid solidification process.
\end{abstract}

\section{Introduction}

Rapid solidification involves cooling of metallic melts at rates $>10^{4} \mathrm{~K} / \mathrm{s}$ and results in significant microstructural and constitutional changes. The microstructural modifications include grain refinement and reduced segregation effects while the constitutional changes include formation of supersaturated solid solutions and metastable crystalline intermediate and amorphous phases. These effects, either alone or in combination, have improved the mechanical behavior and performance of the rapidly solidified alloys and these results were especially significant for lightweight metals and have been well documented in the literature [1-5]. Eutectic Al-Si alloys are a wide range of useful materials in different fields of industry where high strength to weight ratio, castability, and wear resistance are required [6-10]. The importance of Al$\mathrm{Si}$ and Al-Si-X alloys for automotive applications with some engine parts like connecting rod, cylinder sleeve, piston and valve retainer, and compressor parts like rotary compressor vane and shoe disc has been well established [11].

The effects of a third element addition to Al-Si alloys such as iron, copper, nickel, and other transition elements have been investigated [12-16]. These transition elements, when alloyed in various combinations with aluminum, form fine dispersions of high-modulus second-phase particles, resulting in increased strength, wear resistance, and thermal stability [17].

Due to the high liquid solubility and the low solid solubility of $\mathrm{Fe}$ in $\mathrm{Al}-\mathrm{Si}$ alloys, $\mathrm{Fe}$ has various ways to come into the molten of these alloys and promotes to form various $\mathrm{Fe}$-rich intermetallic phases such as $\mathrm{Al}_{8} \mathrm{Fe}_{2} \mathrm{Si}(\alpha)$ and $\mathrm{Al}_{5} \mathrm{FeSi}(\beta)$ [18-20]. In addition, this feature ensures its high chemical homogeneity in the $\alpha$-Al and its thermal stability. The solubility of $\mathrm{Fe}$ in $\mathrm{Al}$ can be extended up to $0.6 \mathrm{wt} . \%$ by rapid solidification [21]. Therefore, it is expected that the Fecontaining phases may be formed during postsolidification 
process including hot forming. However, it is well known that $\beta$-phase, formed in as cast aluminum alloys when $\mathrm{Fe}$ is present, is a brittle intermetallic phase and regarded as the most harmful element degrading mechanical properties of these alloys [20, 22-27]. Moreover, it is found that the dimension of the $\beta$-phase crystals increases with increasing of Fe content and decreasing of cooling rate [28]. Suppression of the $\beta$-phase can occur by increasing the cooling rates to typical for rapid solidification processes $\left(10^{6} \mathrm{~K} / \mathrm{s}\right)$ [28]. The ternary $\mathrm{Al}-\mathrm{Si}-\mathrm{Fe}$ has been extensively studied using rapid solidification techniques $[15,16]$, including melt spinning [12]. The present investigation aims to study the microstructural characterization of high Fe containing near-eutectic Al-Si rapidly solidified alloy, namely, Al-11 wt.\% Si-11 wt.\% Fe. For this purpose, X-ray diffraction (XRD), scanning electron microscopy (SEM), and energy dispersive X-ray spectrometer (EDS) techniques were carried out on both alloys. Hardness of the ribbons was also measured.

\section{Experimental Details}

2.1. Material Preparation. A ternary near-eutectic high Fe containing Al-11 wt.\% Si-11 wt.\% Fe alloy was prepared from 99.8 wt.\% pure $\mathrm{Al}, 99.75$ wt.\% pure $\mathrm{Fe}$, and $\mathrm{Al}-10 \mathrm{wt} . \% \mathrm{Si}$ master alloy. The ingots were melting in a muffle furnace and poured into a graphite mold after the homogenization process to produce rods of $25 \mathrm{~mm}$ in length and $4 \mathrm{~mm}$ in diameter. Long uniform ribbons of thickness $50 \mu \mathrm{m}$ and width $2 \mathrm{~mm}$ were prepared by melt spinning. A stream of the molten alloy, at $950^{\circ} \mathrm{C}$, was ejected by argon gas at a gauge pressure of 1.5 bars from a silica tube with a $0.4 \mathrm{~mm}$ orifice diameter. The melt jet fell on a copper disc of $18 \mathrm{~cm}$ diameter coated by chromium, rotating at $2950 \mathrm{rpm}$. The estimated cooling rate was about $10^{5} \mathrm{~K} / \mathrm{s}$. The produced ribbons were fairly uniform. Deviations of $0.05 \% \mathrm{~mm}$ and $3 \mu \mathrm{m}$ in width and thickness were observed from the whole length of ribbons.

2.2. Material Characterization. XRD patterns were performed using a 1390 Philips diffractometer with filtered $\mathrm{Cu}$ $K \alpha$ radiation at $40 \mathrm{kV}$ and $20 \mathrm{~mA}$. The X-ray samples were performed from a short length stuck on a glass slide using Vaseline. Microstructure characterizations were performed by scanning electron microscopy. SEM investigations were carried out in a JEOL JSM-T330 scanning electron microscope operated at $25 \mathrm{kV}$ and linked with an energy dispersive spectrometry (EDS) attachment. The ribbons were observed for the wheel side surface using standard metallographic techniques. Optical mount specimens were prepared for SEM investigations followed by chemical etching in a $0.5 \% \mathrm{HF}$ solution. The annealed samples were heated at $350^{\circ} \mathrm{C} / 25 \mathrm{~h}$. Hardness was measured at room temperature using the Vickers hardness Leitz Wetzlar Germany instrument with loads of $25 \mathrm{~g}$. A total of 10 measurements were performed on the longitudinal section of each ribbon and the average is taken as the microhardness value. In the present study, Rietveld X-ray diffraction analysis [29] was carried out by the X'pert HighScor 2004 program and the Pseudo-Voigt peak shape function. The reliability of the refinement results was judge by the pattern $R$ factor $\left(R_{\mathrm{p}}\right)$, the weighted pattern $R$ factor $\left(R_{\mathrm{wp}}\right)$, and the "goodness of fit" (GOF $\left.=\left(R_{\mathrm{wp}} / R_{\mathrm{xp}}\right)^{2}\right)$ [30]. Initial structure parameters of all phases used for Rietveld method in this study were from ICCD (Inorganic Crystal Structure Database) cards. The parameters that had been refined simultaneously include scale factors, zero point shift, lattice parameters, atomic coordinates, atomic sites occupancies, isotropic or anisotropic temperature factors, profile shape parameter, FWHM (full width at half maximum) parameters, asymmetry and preferred orientation parameters. The total parameters to be refined of Al-11Si-11Fe melt spun and annealed ribbons were 26 and 51, respectively. Rietveld method is becoming progressively more popular for microstructure characterization of materials. It is common practice to estimate domain size and strain values from the refined profile width parameters. Moreover, weight fractions of all phases in multiphase sample can be calculated directly by their scale factors which can be obtained by Rietveld fitting. The relationship between the fraction $\left(W_{i}\right)$ for each phase $i$ and its scale factor $\left(S_{i}\right)$ determined is obtained from the following relation [30]:

$$
W_{i}=\frac{S_{i}(Z M V)}{\sum_{i=1}^{n} S_{i}(Z M V)_{i}},
$$

where $Z, M$, and $V$ are the numbers of formula unite cell, unit molecular weight of the formula, and unit cell volume of phase $i$ in a mixture of $n$ phases, respectively. Weight fraction of all phases observed in this work, crystallite size of and microstrain\% of $\alpha$-Al have been estimated using Rietveld Xray diffraction analysis.

\section{Results and Discussion}

3.1. Scanning Electron Microscopy. It was reported that the intermetallic phases $\alpha$ and $\beta$ observed in Fe-containing AlSi alloys follow another solidification path under nonequilibrium solidification condition which leads to the formation of metastable forms of $\alpha$ and $\beta$ with different compositions [3135]. Rapid solidification is considered as a nonequilibrium process; therefore it is expected to obtain a metastable $\alpha$ and $\beta$ phases. The representative microstructures of the investigated melt spun alloy are shown in Figure 1. An ultra-fine dendritic primary $(\mathrm{Al})$ phase, together with a very fine eutectic ( $\mathrm{Al})$, is observed as shown in Figure 1(a). This eutectic Al has a large amount of Si and Fe as deduced by EDS shown in Figure 1(b). Moreover, a large number of tiny needle-shaped $\beta$-phase particles (about $0.5 \mu \mathrm{m}$ thickness and $5 \mu \mathrm{m}$ width) are present and distributed in the eutectic region as shown in Figure 1(c). Chemical composition of these needle shape particles has been deduced by EDS and shown in Figure 1(d). Besides, a large number of ultra-fine cubic $\alpha$-phase particles are present as shown in Figure 1(e). Chemical composition of these cubic particles has been deduced by EDS and shown in Figure 1(f). The chemical compositions of intermetallic compounds $(\alpha$ and $\beta$ phases) observed in the rapidly solidified Al-11Si$11 \mathrm{Fe}$ and measured by EDS are summarized in Table 1. This fine microstructure of $\alpha$ and $\beta$-phase can be related to the high cooling rate obtained in the rapid solidification process 


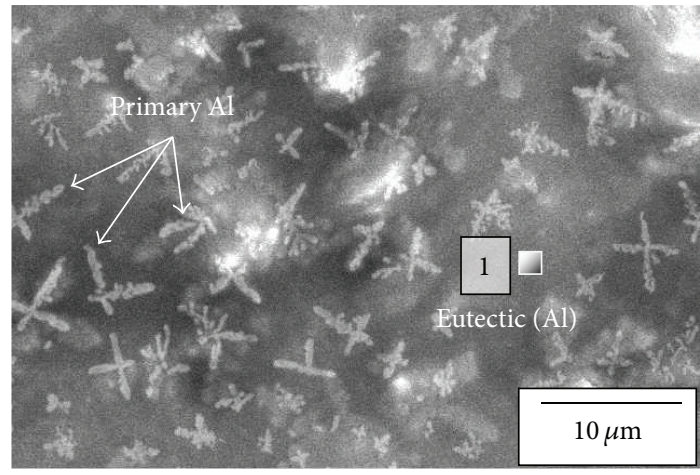

(a)

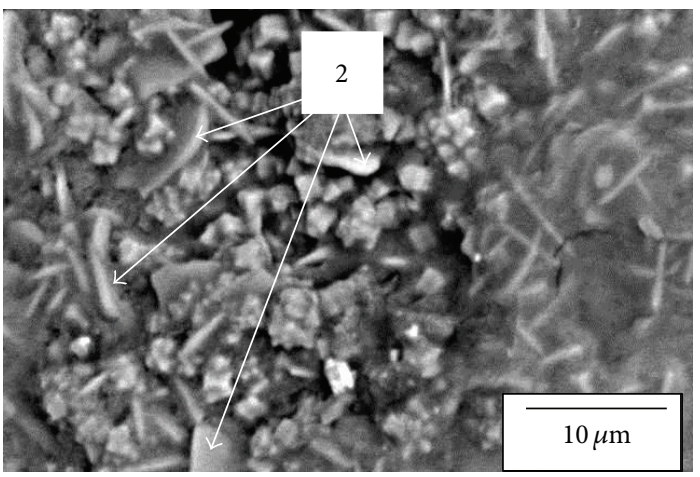

(c)

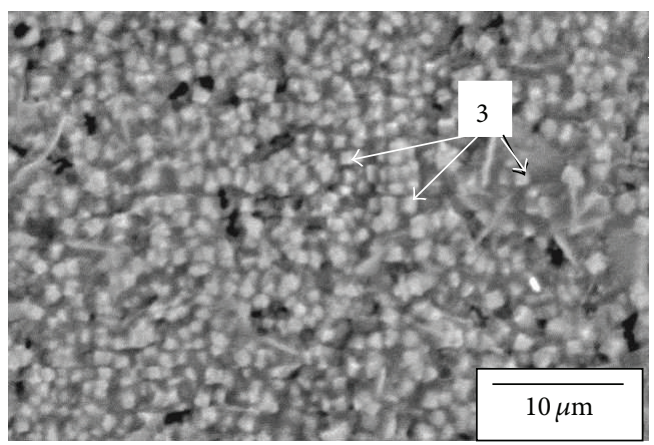

(e)

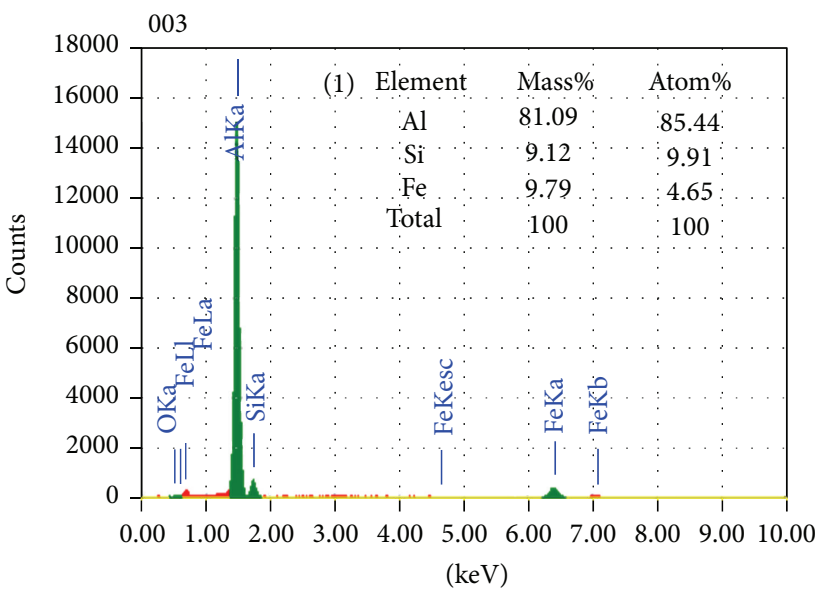

(b)

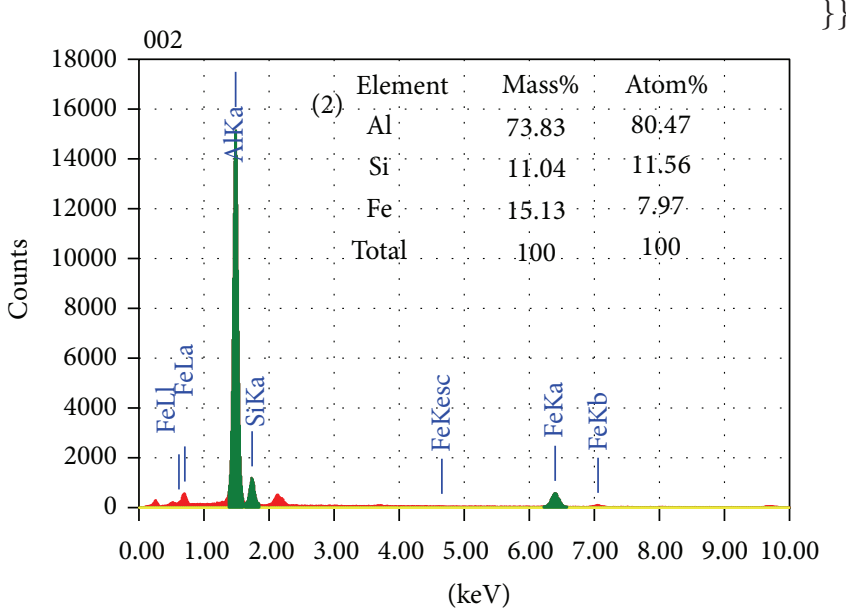

(d)

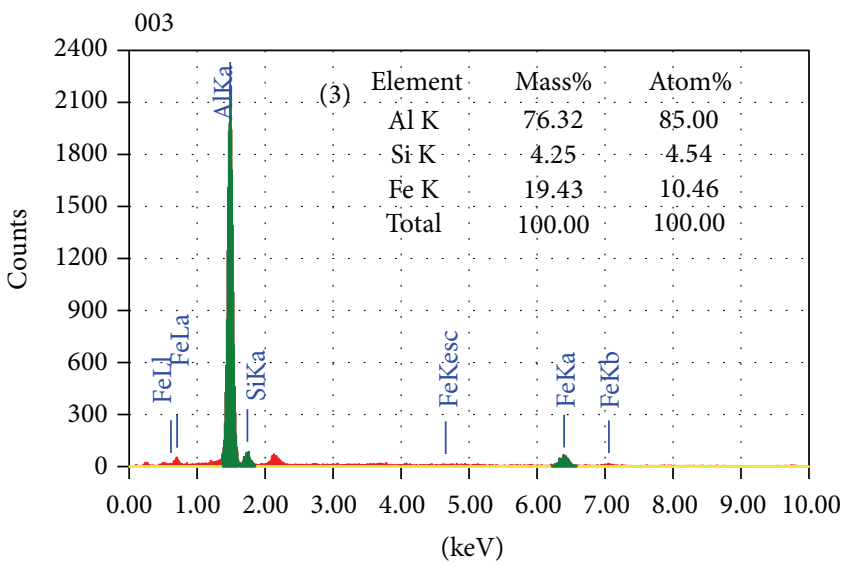

(f)

Figure 1: SEM micrographs of Al-11Si-11Fe as-spun samples (a), (c), and (e) and the corresponding EDS-spectra (b), (d), and (f); additional red signals are corresponding to oxygen and carbon.

which inhibits the formation of coarse phases. Moreover, $\beta$ particles grow easily straight along the lengthwise direction. It was found that the length distribution of the existing $\beta$ particles were very diverse from $1 \mu \mathrm{m}$ to $5 \mu \mathrm{m}$. All phases observed in the rapid solidified alloy at room temperature are expected except $\alpha$-phase. For the chemical composition range of this alloy, under equilibrium solidification condition, the first solid phase $\gamma$ begins to crystallize at $829^{\circ} \mathrm{C}$ as shown in Figure 2. As the temperature drops, the primary $\gamma$ phase continuous to precipitate out of the liquid. As the temperature 
TABLE 1: Average chemical compositions of intermetallic compounds ( $\alpha$ and $\beta$ ) observed in high Fe containing near-eutectic Al-Si alloys prepared by rapid solidification as deduced by EDS analysis.

\begin{tabular}{lcccc}
\hline \multirow{2}{*}{ Specimen } & \multirow{2}{*}{ Phase } & \multicolumn{4}{c}{ chemical composition atomic \% } \\
& & $\mathrm{Al}$ & $\mathrm{Fe}$ & $\mathrm{Si}$ \\
\hline \multirow{2}{*}{ Al-11Si-11Fe } & $\alpha$ & 85.00 & 10.46 & 4.54 \\
& $\beta$ & 80.47 & 7.97 & 11.56 \\
\hline
\end{tabular}

drops further, the $\gamma$ and $\alpha$ phases crystallize and the liquid composition moves to the quasi-peritectic reaction point $\mathrm{U}_{1}$. At point $\mathrm{U}_{1}$ the primary $\beta$-phase begins to crystallize. As $\alpha$ and $\beta$-phase crystallize, the liquid composition moves to the quasiperitectic reaction point $\mathrm{U}_{3}$ of $\mathrm{L}+\alpha \rightarrow(\mathrm{Al})+\beta\left(612^{\circ} \mathrm{C}\right)$. At point $\mathrm{U}_{3}$, the primary $(\mathrm{Al})$ phase begins to crystallize. The formation of the $(\mathrm{Al})$ and $\beta$-phases continues until the liquid composition reaches point $\mathrm{E}_{1}$. Finally, the eutectic $\beta$-phase is formed together with the $(\mathrm{Al})$ and $(\mathrm{Si})$ phases by the ternary eutectic reaction E1 until all of the liquid is exhausted [36]. However, under nonequilibrium solidification condition in rapid solidification process, due to the high cooling rate, the quasiperitectic reaction was not completed and the $\alpha$ phase could not be transformed totally into an equilibrium $\beta$-phase. Therefore both $\alpha$-phase and $\beta$-phase are observed in the final microstructure of the rapidly solidified Al-11Si$11 \mathrm{Fe}$ alloy. Similar incomplete peritectic reaction has been reported [37] in rapidly solidified Al-17Si-6Fe- $4.5 \mathrm{Cu}-0.5 \mathrm{Mg}$ alloy, since $\beta$-phase is totally disappeared and replaced by $\mathrm{Al}_{9} \mathrm{FeSi}_{3}$ in a metastable state.

In order to prove the elements are constituted in the examined rapidly solidified alloy represented in Figure 3(d), elemental maps were performed for the elements line Al$\mathrm{K}, \mathrm{Si}-\mathrm{K}$, and Fe-K as shown in Figures 3(a), 3(b), and 3(c), respectively. The maximum pixel spectrum clearly shows the presence of $\mathrm{Al}, \mathrm{Si}$, and $\mathrm{Fe}$ in the scanned microstructure. The corresponding EDS spectra and chemical composition are represented in Figure 3(e). A large number of a fine sphericalshaped intermetallic phase particles are observed as shown in Figure 3(d) and corresponding EDS spectra are illustrated in Figure 3(f).

It is obvious that these particles have a chemical composition similar to $\beta$-phase observed in Figure 1(c). Comparing between chemical composition of course $\beta$-phase obtained in equilibrium solidification condition ( $25.6 \mathrm{wt} . \%$ $\mathrm{Fe}, 12.8 \mathrm{wt} . \% \mathrm{Si}$ ) [22] and fine microstructural $\beta$-phase obtained in nonequilibrium solidification condition (as in our case: $14.87-15.13 \mathrm{wt} . \% \mathrm{Fe}, 10.98-11.04 \mathrm{wt} . \% \mathrm{Si}$ ), we found that rapid solidification has a great influence on the Fe content of the $\beta$-phase. It is clear that Fe content of rapidly solidified $\beta$-phase has been lowered during rapid solidification process. Nanosized Si particles obtained in rapidly solidified Al-Si base alloys make it difficult to be observed in SEM regime. The average dendrite arm spacing measured from the SEM micrographs for the as-melt spun alloy is about $0.65 \mu \mathrm{m}$ as extracted from SEM micrograph shown in Figure 1(a). Using the relationship introduced by Matyja et al. [38], this value corresponds to a cooling rate of $1.2 * 10^{5} \mathrm{~K} / \mathrm{s}$. It is obvious that the estimated cooling rate for the as-melt spun Al-11Si-11Fe

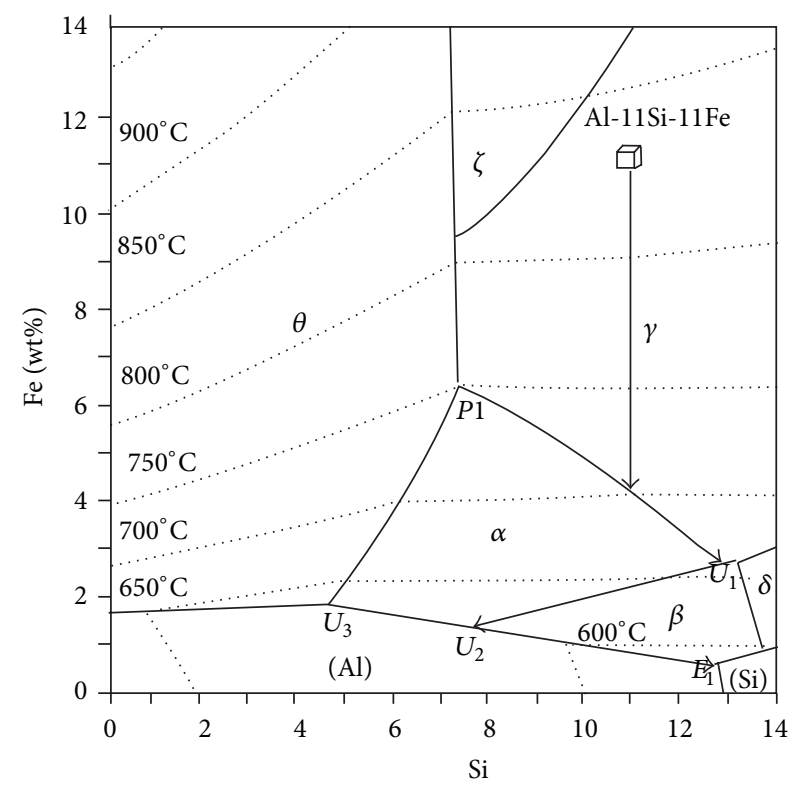

FIGURE 2: Calculated liquidus projection and isotherms in the Alrich corner of the Al-Si-Fe system and the predicted equilibrium solidification paths [36].

alloy is less than $10^{6} \mathrm{~K} / \mathrm{s}$ and this may explain why we could not obtain total suppression of $\beta$-phase but partially instead.

3.2. X-Ray Diffraction and DSC. Figure 4 represents the observed (points), calculated (solid line) diffraction patterns, and difference curve above (the red line) for Al-11Si-11Fe asmelt spun Figure 1(a) and annealed (b). Successful agreement is obtained between the observed and calculated diffraction patterns. The $R$ factors obtained from the Rietveld method are typical and satisfactory as shown in Table 2. In addition to the supersaturated solid solution $\alpha$ - $\mathrm{Al}$ phase, $\mathrm{Al}_{4.5} \mathrm{FeSi}$ and $\mathrm{Al}_{8} \mathrm{SiFe}_{2}$ intermetallic phases have been indexed with estimated contents of $10.1 \mathrm{wt} . \%$ and $1.1 \mathrm{wt} \%$, respectively. Moreover, a very weak and broad XRD peaks corresponding to $\mathrm{Si}$ have been detected with estimated content of $2.9 \mathrm{wt} . \%$ $\mathrm{Si}$. The average crystallite size and induced microstrain\% of Si are $16.5 \mathrm{~nm}$ and 0.196 , respectively. Figures 5 and 6 illustrate the calculated profile (red line) of $\mathrm{Al}_{4.5} \mathrm{FeSi} \beta$ phase in $40^{\circ}-48^{\circ} 2 \theta$ range for as-melt spun and annealed alloys, respectively. It is evident from Figure 5 that the $\beta$ phase has a little strong corresponding XRD lines at 41.95, $42.07,42.25,43.5$, and $45.2^{\circ}$. The average crystallite size and induced microstrain\% of $\beta$-phase in the as-melt spun state are $40 \mathrm{~nm}$ and 0.225 , respectively. Through annealing process $\left(350^{\circ} \mathrm{C} / 25 \mathrm{~h}\right)$, the corresponding XRD lines of $\mathrm{Al}_{4.5} \mathrm{FeSi} \beta$ phase become much stronger indicating coarsening of the $\mathrm{Al}_{4.5} \mathrm{FeSi} \beta$-phase with average crystallite size and induced microstrain of $44 \mathrm{~nm}$ and 0.073 , respectively.

Considering the solid solubility of Fe in $\alpha-\mathrm{Al}$ is nil and using the linear relationship between lattice parameter and the atomic fraction of Si given by Bendijk et al. [39], a solid solubility extension of 1 at.\% $\mathrm{Si}$ for the as-spun sample can be determined. The influence of heat treatment at $300^{\circ} \mathrm{C}$ 


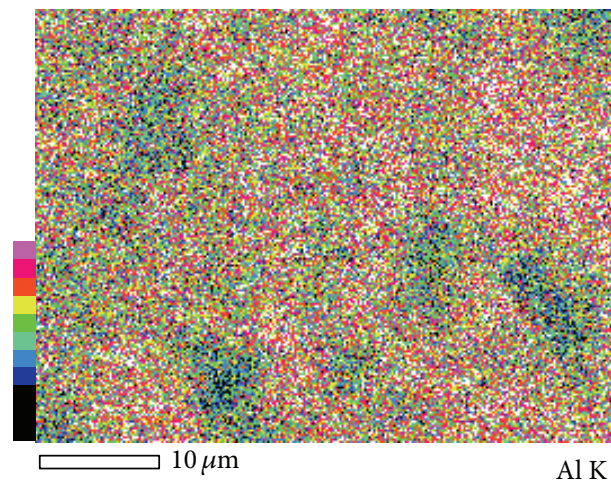

(a)

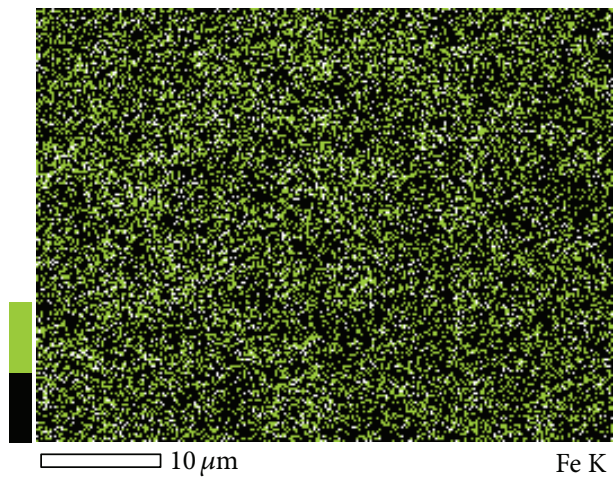

(c)

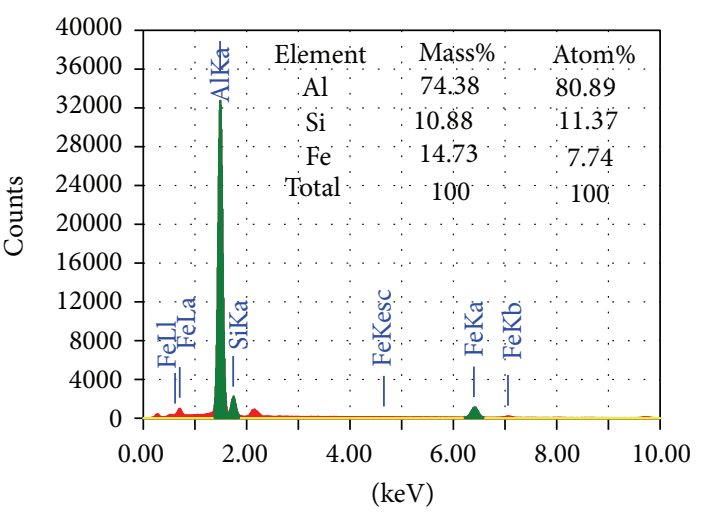

(e)

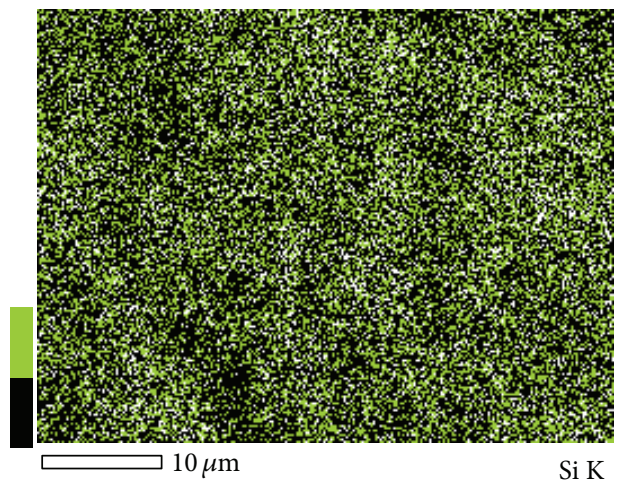

(b)

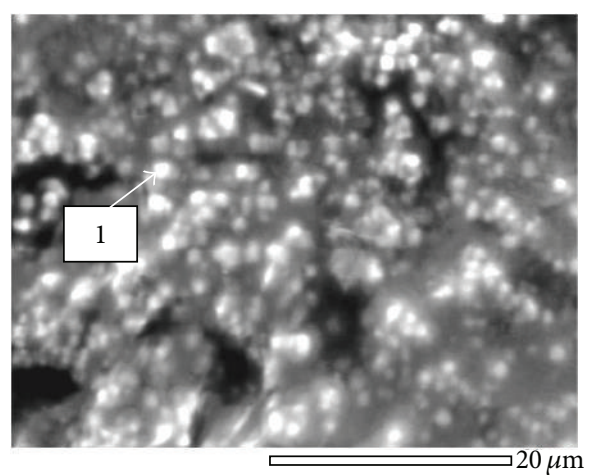

(d)

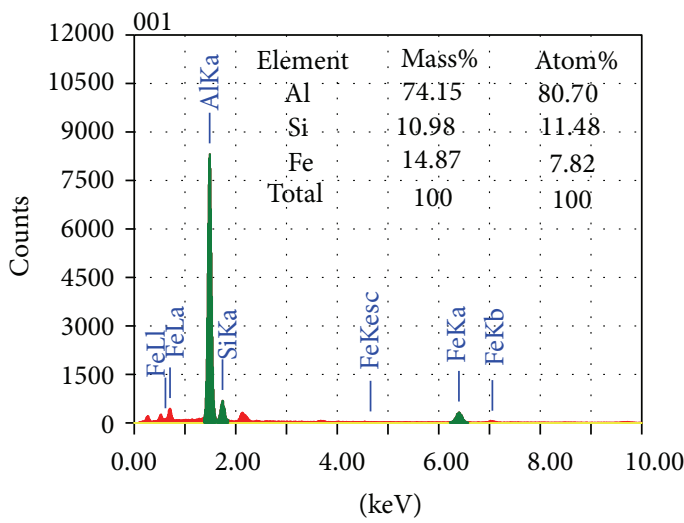

(f)

FIGURE 3: SEM micrograph of Al-11Si-11Fe as-spun alloy (d); corresponding elemental maps of Al (a), Si (b), and Fe (c); corresponding EDSspectra (e) and EDS-spectra of point 1 (f); additional signals are corresponding to oxygen and carbon.

for 25 hours on Al-11Si-11Fe as-spun sample appeared in the increasing of the $\mathrm{Al}_{4.5} \mathrm{FeSi}$ and $\mathrm{Si}$ contents to $35 \mathrm{wt} . \%$ and $5.1 \mathrm{wt} . \%$, respectively. No XRD lines corresponding to Fe could be detected. The estimated crystallite size and microstrain $\%$ of $\alpha$-Al for the as-melt spun alloy are $27 \mathrm{~nm}$ and 0.126 , respectively, as shown in Table 2. After prolonged annealing $\left(350^{\circ} \mathrm{C} / 25 \mathrm{~h}\right)$ the estimated crystallite size and microstrain \% of $\alpha$-Al become $29 \mathrm{~nm}$ and 0.072 , respectively.

Figure 7 shows the respective DSC data for the asmelt spun Al-11Si-11Fe alloy scanned at a rate of $10^{\circ} \mathrm{C} / \mathrm{min}$ between 50 and $500^{\circ} \mathrm{C}$. The DSC scan exhibits a small shallow exothermic peak indicating the existence of large amount of Si nanoparticles in as-spun state and coarsening of the Si nanoparticles occurs at $374.3^{\circ} \mathrm{C}$. Similar exothermic peak corresponding to $\mathrm{Si}$ coarsening has been reported at $348^{\circ} \mathrm{C}$ for Al-7.7Si-3.3Fe rapidly solidified alloy [13].

\section{Microhardness}

Comparing to hardness of as cast counterpart alloy (hardness $=115 \mathrm{HV}$ ), a significant improvement of hardness for asspun Al-11Si-11Fe alloy has been obtained. The as-spun alloy exhibits microhardness as high as $270 \mathrm{HV}$. Figure 8 represents 
TABLE 2: Rietveld refinement results for Al-11Si-11Fe melt spun and annealed $\left(350^{\circ} \mathrm{C} / 25 \mathrm{~h}\right)$ ribbons.

\begin{tabular}{lcccccc}
\hline \multirow{2}{*}{ Sample } & \multirow{2}{*}{ Lattice parameter $\alpha-\mathrm{Al}(\mathrm{nm})$} & \multirow{2}{*}{ Crystallite size $(\mathrm{nm}) \alpha$-Al } & Strain. $\varepsilon \%$ & \multicolumn{3}{c}{ Agreement factors } \\
& & & $R_{\mathrm{P}}$ & $R_{\mathrm{WP}}$ & $R_{\mathrm{ex}}$ & $\mathrm{GOF}$ \\
\hline Melt spun & 0.404753 & 27 & 0.126 & 5.7 & 7.8 & 7.4 \\
Annealed & 0.40501 & 29 & 0.072 & 5.3 & 7.1 & 6.5 \\
\hline
\end{tabular}

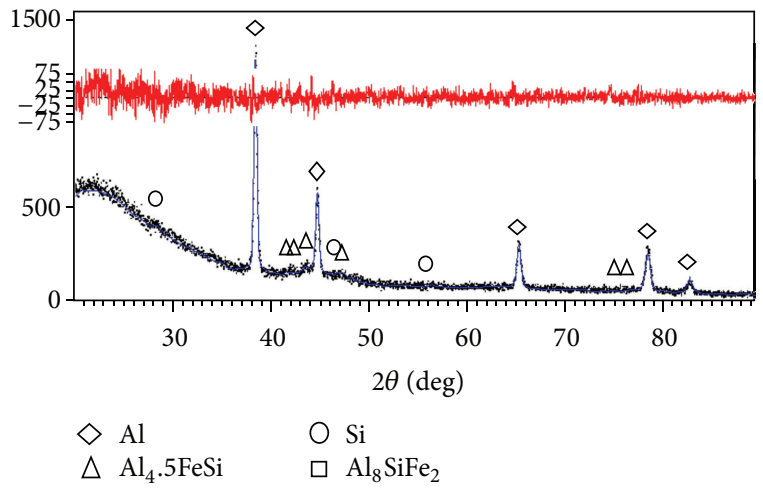

(a)

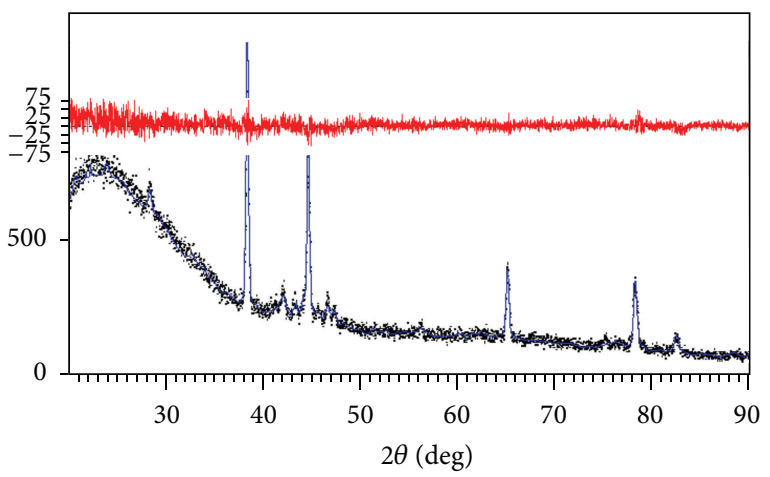

(b)

FIGURE 4: Observed profile (points), calculated profile (the solid line), and the profile difference above for the Rietveld patterns of Al-11Si-11Fe melt spun (a) and annealed at $350^{\circ} \mathrm{C} / 25 \mathrm{~h}$ (b) alloys.

development of the microhardness for the Al-11Si-11Fe asmelt spun alloy during annealing at elevated temperature of $150^{\circ} \mathrm{C}$. Further increase of microhardness up to $450 \mathrm{HV}$ after 12 hours at $150^{\circ} \mathrm{C}$ has been obtained. After prolonged annealing (at $350^{\circ} \mathrm{C} / 25 \mathrm{~h}$ ) hardness decreases to $190 \mathrm{HV}$. This improvement of microhardness for the as-melt spun alloys can be related to the supersaturated solid solution of $\alpha$-Al with $\mathrm{Si}$, fine structural low Fe-containing needle and spherical shape $\beta$-phase, and ultra-fine hard Si particles. Microhardness for as-spun Al-Si base alloys is expected to decrease by increasing of annealing time even at low elevated temperature as $150^{\circ} \mathrm{C}$ due to the precipitation solutes from the supersaturated solid solution $\alpha$-Al [40]. Instead, it increases by increasing of the annealing time at the first stage and then decreases. This increase of hardness with time during the first stage may be related to precipitation of much ultra-fine $\beta$-phase particles before Si precipitation from the supersaturated solid solution $\alpha$-Al becomes effective and

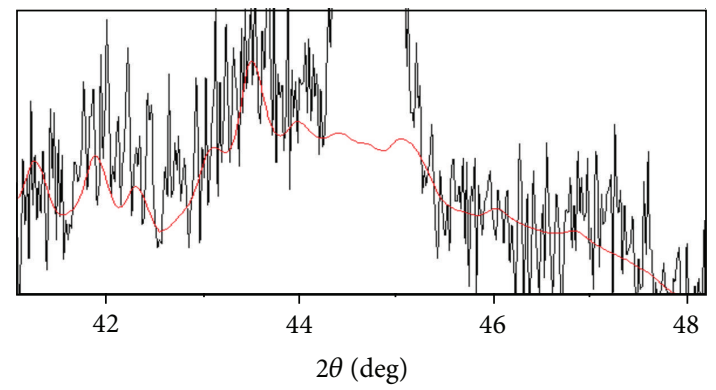

FIGURE 5: Expanded XRD pattern for as-melt spun Al-11Si-11Fe alloy showing part of the calculated profile (red line) of $\mathrm{Al}_{4.5} \mathrm{SiFe} \beta$-phase in as-quenched state.

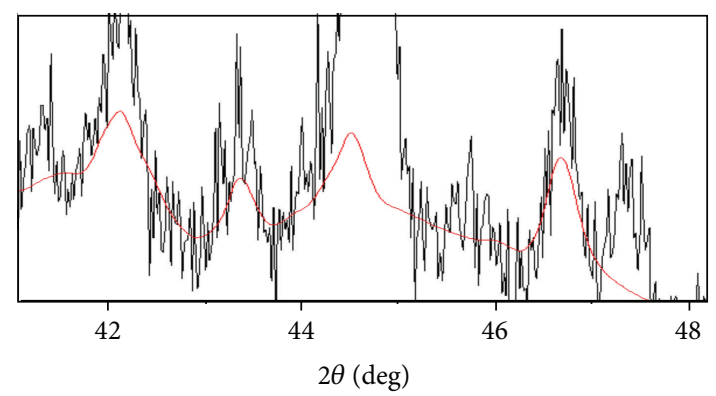

FIGURE 6: Expanded XRD pattern for annealed $\left(350^{\circ} \mathrm{C} / 25 \mathrm{~h}\right) \mathrm{Al}-11 \mathrm{Si}-$ $11 \mathrm{Fe}$ alloy showing part of the calculated profile (red line) of $\mathrm{Al}_{4.5} \mathrm{SiFe}$ $\beta$-phase.

before $\beta$-phase becomes coarser at the second stage during the heat treatment process.

\section{Conclusions}

Microstructure and microhardness of $\mathrm{Al}-11 \mathrm{Si}-11 \mathrm{Fe}$ rapidly solidified alloy have been improved as deduced by SEM, EDS, $\mathrm{XRD}$, and microhardness measurements. Rapid solidification with estimated cooling rate of $1.2 * 10^{5} \mathrm{~K} / \mathrm{s}$ has lowered $\mathrm{Fe}$ content of $\beta$-phase particles as deduced by EDS analysis and suppressed the formation of $\beta$-phase incompletely. Besides, rapid solidification has a great influence on the morphology of $\beta$ phase since these phase particles become very fine with straight needle shape (with $0.5 \mu \mathrm{m}$ thickness and $5 \mu \mathrm{m}$ width) not with curved shape as compared with its classically solidified counterpart. The estimated content of the as-melt spun $\beta$-phase is $10.1 \mathrm{wt} . \%$. Solid solubility of $\mathrm{Si}$ in $\alpha$-Al has been extended to $1 \mathrm{wt} . \%$. Si nanoparticles in as-melt spun state coarsened at temperature of $374.3^{\circ} \mathrm{C}$ as deduced by DSC analysis with estimated content of $2.9 \mathrm{wt} . \%$ as deduced by 


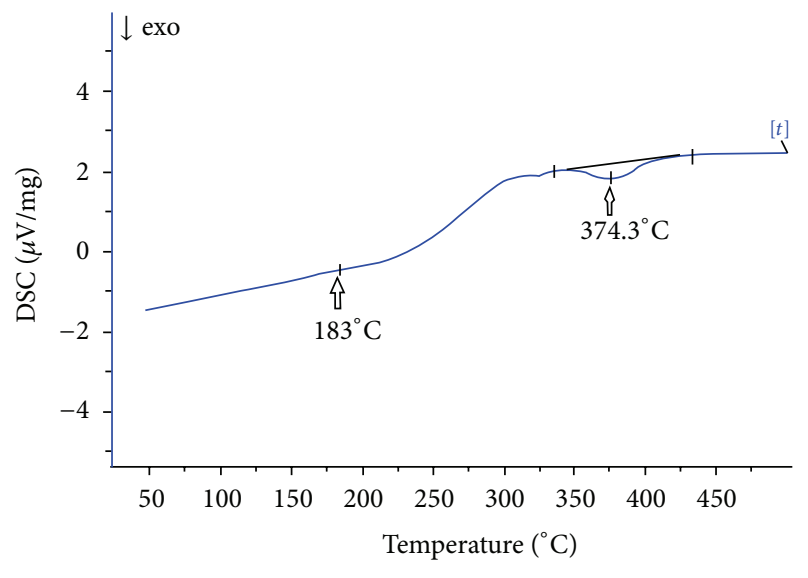

FIGURE 7: DSC curve of the melt-spun Al-11Si-11Fe alloy ribbon scanned at the heating rate of $10^{\circ} \mathrm{C} / \mathrm{min}$ between 50 and $500^{\circ} \mathrm{C}$.

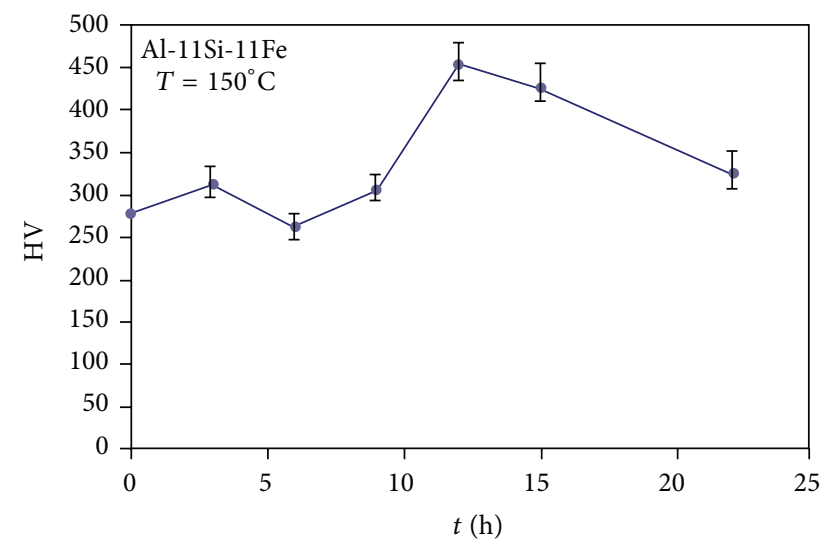

FIGURE 8: Variation of hardness (HV) with time (h) at $150^{\circ} \mathrm{C}$.

XRD analysis. The average crystallite size and microstrain of $\alpha$-Al in as-melt spun state were $27 \mathrm{~nm}$ and 0.125 , respectively. During annealing process $\left(350^{\circ} \mathrm{C} / 25 \mathrm{~h}\right)$, the estimated contents of both $\beta$-phase and Si phases increased to $35 \mathrm{wt} . \%$ and $5.1 \mathrm{wt} . \%$, respectively. Microhardness value of the melt spun ribbons was as high as $277 \mathrm{HV}$ and further improved up to $450 \mathrm{HV}$ during heat treatment at $150^{\circ} \mathrm{C} / 12 \mathrm{~h}$. This improvement of microhardness can be related to the influence of rapid solidification for microstructure refinement and modification occurring for the Al-11Si-11Fe as-melt spun alloy.

\section{Conflict of Interests}

The authors declare that there is no conflict of interests regarding the publication of this paper.

\section{References}

[1] C. Suryanarayana, Non-Equilibrium Processing of Materials, Elsevier, Oxford, UK, 1999.

[2] S. K. Das, B. H. Kear, and C. M. Adam, Rapidly Solidified Crystalline Alloys, TMS-AIME, Warrendale, Penn, USA, 1985.
[3] H. H. Liebermann, Ed., Rapidly Solidified Alloys, Marcel Dekker, New York, NY, USA, 1993.

[4] T. R. Anantharaman and C. Suryanarayana, Rapidly Solidified Metals, Trans Tech Publications, Aedermannsdorf, Switzerland, 1987.

[5] C. Suryanarayana, S. F. H. Froes, S. Krishnamurthy, and Y.W. Kim, "Development of light alloys by rapid solidification processing," International Journal of Powder Metallurgy, vol. 26, no. 2, pp. 117-129, 1990.

[6] J. E. Gruzleski and B. M. Closet, The Treatment of Liquid Aluminum-Silicon i, American Foundrymen's Society, Des Plaines, Ill, USA, 1990.

[7] I. J. Polmea, Light Alloys: Metallurgy of the Light Metals, Edward Arnold, London, UK, 2nd edition, 1989.

[8] N. Saheb, T. Laoui, A. R. Daud, M. Harun, S. Radiman, and R. Yahaya, "Influence of $\mathrm{Ti}$ addition on wear properties of $\mathrm{Al}-\mathrm{Si}$ eutectic alloys," Wear, vol. 249, no. 8, pp. 656-662, 2001.

[9] H. Ye, "An overview of the development of Al-Si-Alloy based material for engine applications," Journal of Materials Engineering and Performance, vol. 12, no. 3, pp. 288-297, 2003.

[10] S. P. Nikanorov, M. P. Volkov, V. N. Gurin et al., "Structural and mechanical properties of Al-Si alloys obtained by fast cooling of a levitated melt," Materials Science and Engineering A, vol. 390, no. 1-2, pp. 63-69, 2005.

[11] W. H. Hunt Jr., "New directions in Aluminium based P/M materials for automotive applications," The International Journal of Powder Metallurgy, vol. 6, pp. 51-60, 2000.

[12] N. Ünlü, A. Genç, M. L. Öveçoğlu, N. Eruslu, and F. H. Froes, "Characterization investigations of melt-spun ternary $\mathrm{Al}-\mathrm{xSi}-$ 3.3Fe ( $\mathrm{x}=10,20$ wt.\%) alloys," Journal of Alloys and Compound, vol. 322, no. 1-2, pp. 249-256, 2001.

[13] N. Ünlü, A. Genç, M. L. Öveçoğlu, E. J. Lavernia, and F. H. Froes, "Microstructural evolution during annealing of the melt-spun ternary hypoeutectic $\mathrm{Al}-7.6 \mathrm{Si}-3.3 \mathrm{Fe}$ (in wt.\%) alloy," Journal of Alloys and Compound, vol. 343, no. 1-2, pp. 223-233, 2002.

[14] J. Zhou, J. Duszczyk, and B. M. Korevaar, "Structural development during the extrusion of rapidly solidified Al-20Si-5Fe3Cu-1Mg alloy," Journal of Materials Science, vol. 26, no. 3, pp. 824-834, 1991.

[15] T. Hirano, "Properties of Al-Si-X P/M alloys featuring use of rapidly solidified powders," in Proceedings of the Powder Metallurgy World Congress, Y. Bando and K. Kosuge, Eds., pp. 563-566, Kyoto International Conference Center, Kyoto, Japan, 1993.

[16] T. Hirano, F. Ohmi, F. Kiyoto, and T. Fujita, "Development of AlSi-X P/M alloys using rapidly solidified powders," in Proceedings of the International Conference on Rapidly Solidified Materials, P. W. Lee and R. S. Carbonara, Eds., pp. 327-339, San Diego, Calif, USA, 1985 .

[17] J. M. Sater, T. H. Sanders, and R. K. Garrett, "Characterization of rapidly solidified materials," in Proceedings of the Rapidly Solidified Powder Aluminium Alloys Symposium, M. E. Fine and E. A. Starke, Eds., pp. 83-117, April 1984.

[18] N. A. Belov, A. A. Aksenov, and D. G. Eskin, Iron in Aluminum Alloys: Impurity and Alloying Element, Taylor and Francis, London, UK, 2002.

[19] J. A. Taylor, "The effect of iron in Al-Si casting alloys," in Casting Concepts. Proceedings of the 35th Australian Foundry Institute National Conference, J. Couzner, Ed., pp. 148-157, Autralian Foundry Institute, Adelaide, Australia, 2004. 
[20] W. Eidhed, "Soft magnetic properties and microstructure of novel Nb poor Finemet type alloys," Journal of Materials Science and Technology, vol. 24, no. 1, pp. 45-48, 2008.

[21] H. Jones, "Cooling rates in freezing finite slabs," Materials Science and Engineering, vol. 5, no. 5, pp. 297-299, 1970.

[22] L. F. Mondolfo, Aluminum Alloys, Structure and Properties, Butterworths, London, UK, 1976.

[23] A. M. Samuel, F. H. Samuel, C. Villeneuve, H. W. Doty, and S. Valtiera, "Effect of trace elements on Al5FeSi characteristics, porosity and tensile properties in Al-Si-Cu (319) cast alloys," International Journal of Cast Metals Research, vol. 14, pp. 97-120, 2001.

[24] J. Z. Yi, Y. X. Gao, P. D. Lee, and T. C. Lindley, "Effect of Fe-content on fatigue crack initiation and propagation in a cast aluminum-silicon alloy (A356-T6)," Materials Science and Engineering A, vol. 386, no. 1-2, pp. 396-407, 2004.

[25] S. Seifeddine, S. Jhansson, and I. L. Svensson, "The influence of cooling rate and manganese content on the $\beta-\mathrm{Al}_{5} \mathrm{FeSi}$ phase formation and mechanical properties of Al-Si-based alloys," Materials Science and Engineering A, vol. 490, no. 1-2, pp. 385390, 2008.

[26] X. Ma, A. M. Samuel, F. H. Samuel, H. W. Doty, and S. Valtierra, "A study of tensile properties in $\mathrm{Al}-\mathrm{Si}-\mathrm{Cu}$ and $\mathrm{Al}-\mathrm{Si}-\mathrm{Mg}$ alloys: effect of $\beta$-iron intermetallics and porosity," Materials Science and Engineering A, vol. 490, no. 1-2, pp. 36-51, 2008.

[27] S. G. Shabestari, "The effect of iron and manganese on the formation of intermetallic compounds in aluminum-silicon alloys," Materials Science and Engineering A, vol. 383, no. 2, pp. 289-298, 2004.

[28] L. A. Narayanan, F. H. Samuel, and J. E. Gruzleski, "Crystallization behavior of Iron-containing intermetallic compounds in 319 Aluminum alloy," Metallurgical and Materials Transactions A, vol. 25, no. 8, pp. 1761-1773, 1994.

[29] H. M. Rietveld, "Line profiles of neutron powder-diffraction peaks for structure refinement," Acta Crystallographica, vol. 22, pp. 151-152, 1967.

[30] R. A. Young, "The rietveld method," in Introduction To the Rietveld Method, R. A. Young, Ed., Oxford University Press, New York, NY, USA, 1996.

[31] M. V. Kral, "A crystallographic identification of intermetallic phases in Al-Si alloys," Materials Letters, vol. 59, no. 18, pp. 22712276, 2005.

[32] M. Warmuzek and A. Gazda, "Analysis of cooling rate influence on the sequence of intermetallic phases precipitation in some commercial aluminum alloys," Journal of Analytical Atomic Spectrometry, vol. 14, no. 3, pp. 535-537, 1999.

[33] C. J. Simensen and R. Vellasamy, "Determination of phases present in cast material of an Al-0. 5 WT. \% Fe-0. 2 WT. \% Si alloy," Zeitschrift fuer Metallkunde, vol. 68, no. 6, pp. 428-431, 1977.

[34] T. Turmezey, V. Stefániay, and A. Griger, "AlFeSi phases in Aluminium," Key Engineering Materials, vol. 44, pp. 57-68, 1990.

[35] P. Liu, "Crystal structure determination of Al-Fe-Si phases by convergent-beam electron diffraction (CBED)," Key Engineering Materilas, vol. 44-45, pp. 69-86, 1990.

[36] S. Lee, B. Kim, and S. Lee, "Prediction of solidification paths in Al-Si-Fe ternary system and experimental verification: part II. Fe-containing eutectic Al-Si alloys," Materials Transactions, vol. 52, no. 6, pp. 1308-1315, 2011.

[37] J. Shen, Z. Xie, B. Zhou, Q. Li, S. U. Zhijun, and L. E. Hongsheng, "Characteristics and microstructure of a hypereutectic Al-Si alloy powder by ultrasonic gas atomization process," Journal of Materials Science \& Technology, vol. 17, no. 1, pp. 79-80, 2001.

[38] H. Matyja, B. C. Giessen, and N. J. Grant, "The effect of cooling rate on the dendrite spacing in splat-cooled aluminium alloys," Journal of the Institute of Metals, vol. 96, pp. 30-32, 1968.

[39] A. Bendijk, R. Delhez, L. Katgerman, T. H. De Keijser, E. J. Mittemeijer, and N. M. Van Der Pers, "Characterization of AlSi-alloys rapidly quenched from the melt," Journal of Materials Science, vol. 15, no. 11, pp. 2803-2810, 1980.

[40] N. L. Tawfik, E. M. Abdel Hady, and N. E. Kassem, "Hardness and electrical resistivity changes during ageing of rapidly solidified Al-12.5Si-1Mg alloy," Materials Transactions, JIM, vol. 38, no. 5, pp. 401-405, 1997. 

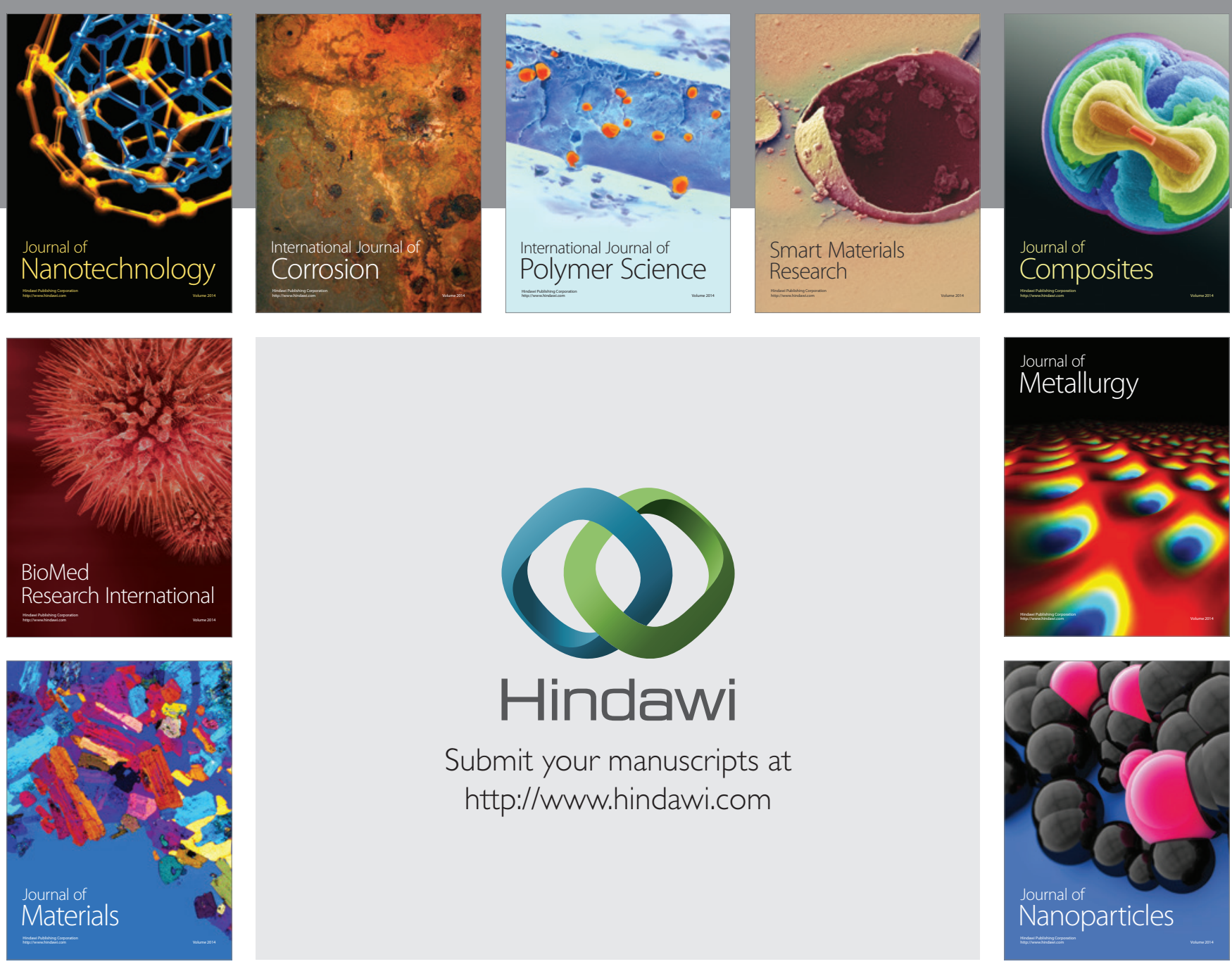

Submit your manuscripts at http://www.hindawi.com
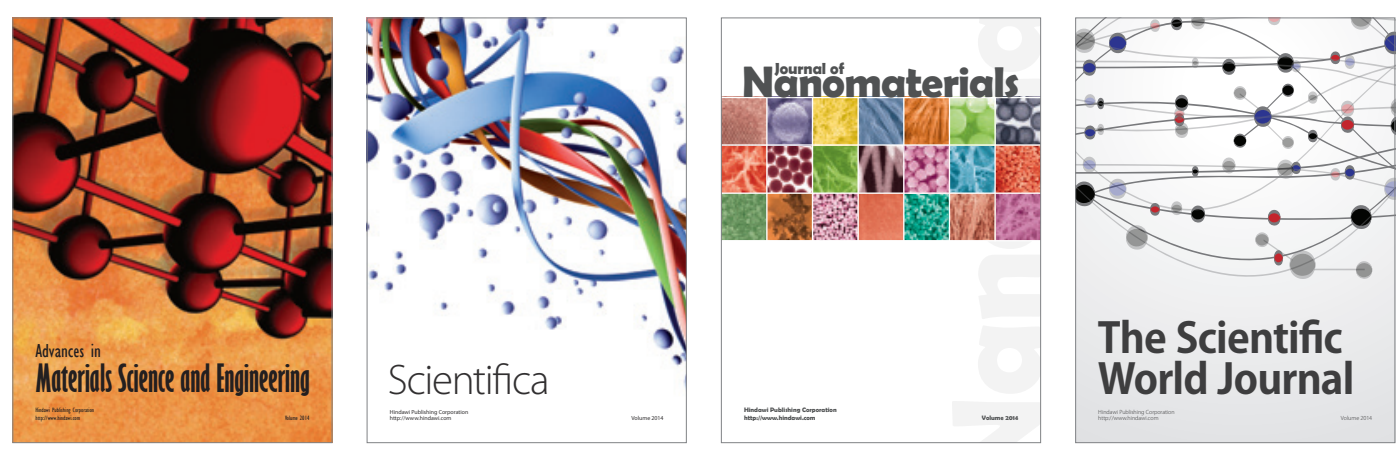

\section{The Scientific World Journal}
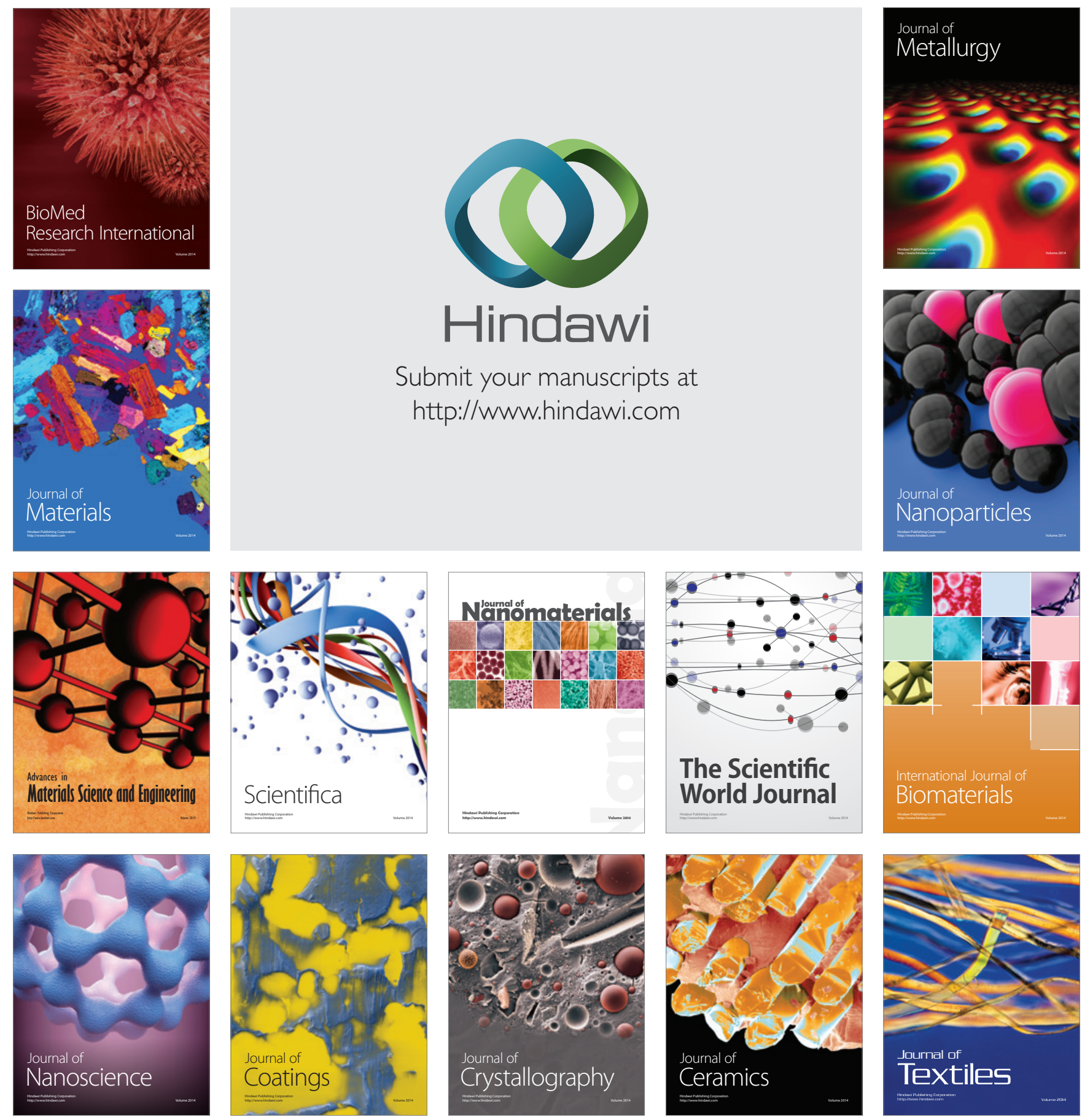